\title{
Ochrobactrum haematophilum sp. nov. and Ochrobactrum pseudogrignonense sp. nov., isolated from human clinical specimens
}

\author{
Correspondence \\ Peter Kämpfer \\ peter.kaempfer@agrar.uni- \\ giessen.de
}

\section{Peter Kämpfer, ${ }^{1}$ Holger C. Scholz, ${ }^{2}$ Birgit Huber, ${ }^{3}$ Enevold Falsen ${ }^{4}$ and Hans-Jürgen Busse ${ }^{3}$}

\author{
${ }^{1}$ Institut für Angewandte Mikrobiologie, Justus-Liebig-Universität Giessen, D-35392 Giessen, \\ Germany \\ ${ }^{2}$ Bundeswehr Institute of Microbiology, D-80937 Munich, Germany \\ ${ }^{3}$ Institut für Bakteriologie, Mykologie und Hygiene, Veterinärmedizinische Universität, A-1210 Wien, \\ Austria \\ ${ }^{4}$ Culture Collection, University of Göteborg, Department of Clinical Bacteriology, SE-413 46 \\ Göteborg, Sweden
}

\begin{abstract}
Three Gram-negative, rod-shaped, non-spore-forming bacteria were isolated from clinical specimens between 1992 and 2000. On the basis of 16S rRNA gene sequence similarities, these strains (CCUG $30717^{\top}$, CCUG 43892 and CCUG $38531^{\top}$ ) were shown to belong to the Alphaproteobacteria, most closely related to Ochrobactrum grignonense (99.0 and 98.2\% similarity to the type strain). Chemotaxonomic data (major ubiquinone Q-10; major polyamines spermidine, sym-homospermidine and putrescine; major polar lipids phosphatidylethanolamine, phosphatidylmonomethylethanolamine, phosphatidylglycerol and phosphatidylcholine; major fatty acids $\mathrm{C}_{18: 1} \omega 7 \mathrm{c}$ and $\mathrm{C}_{19: 0}$ cyclo $\omega 8 \mathrm{c}$ ) supported the affiliation of the isolates to the genus Ochrobactrum. The results of DNA-DNA hybridization and physiological and biochemical tests allowed genotypic and phenotypic differentiation of the isolates from described Ochrobactrum species. Isolates CCUG $30717^{\top}$ and CCUG 43892 were closely related on the basis of DNA-DNA reassociation experiments and therefore represent one novel species, for which the name Ochrobactrum pseudogrignonense sp. nov. is proposed, with the type strain CCUG $30717^{\top}$ (=CIP $109451^{\top}$ ). Isolate CCUG $38531^{\top}$ was different from these strains and also from other Ochrobactrum species. For this strain, the name Ochrobactrum haematophilum sp. nov. is proposed, with the type strain CCUG $38531^{\top}\left(=\operatorname{CIP} 109452^{\top}\right)$.
\end{abstract}

The genus Ochrobactrum was introduced by Holmes et al. (1988) and, at the time of writing, the genus comprises the nine species Ochrobactrum anthropi (Holmes et al., 1988), O. intermedium (Velasco et al., 1998), O. tritici and O. grignonense (Lebuhn et al., 2000), O. gallinifaecis (Kämpfer et al., 2003b), O. lupini (Trujillo et al., 2005), O. oryzae (Tripathi et al., 2006), O. pseudintermedium (ZurdoPiñeiro et al., 2007) and O. cytisi (Teyssier et al., 2007).

Strains CCUG $30717^{\mathrm{T}}$ and CCUG $38531^{\mathrm{T}}$ were isolated in Sweden in 1992 and 1997, respectively, from human blood and strain CCUG 43892 was isolated in Norway in 2000 from a human ear and the strains were presumptively identified as 'O. anthropi-like'. All strains showed beige-coloured colonies

Abbreviations: pNA, $p$-nitroanilide; pNP, $p$-nitrophenyl.

The GenBank/EMBL/DDBJ accession numbers for the 16S rRNA gene sequences of strains CCUG $30717^{\top}$ and CCUG $38531^{\top}$ are respectively AM422371 and AM422370. on nutrient agar (Oxoid) at $37^{\circ} \mathrm{C}$. Subcultivation was done on tryptone soy agar (TSA) at $28{ }^{\circ} \mathrm{C}$ for $48 \mathrm{~h}$.

Gram-staining was performed as described by Gerhardt et al. (1994). Cell morphology was observed under a Zeiss light microscope at $\times 1000$, with cells grown for 3 days at $28{ }^{\circ} \mathrm{C}$ on TSA. The $16 \mathrm{~S}$ rRNA gene was analysed as described by Kämpfer et al. (2003a). Strains CCUG $30717^{\mathrm{T}}$ and CCUG 43892 showed identical 16S rRNA gene sequences. Phylogenetic analysis was performed using the ARB software package (Ludwig et al., 2004) and also the software package MEGA version 2.1 (Kumar et al., 2001) after multiple alignment of data by CLUSTAL_x (Thompson et al., 1997). Distances (distance options according to the Kimura-2 model) were calculated and clustering with the neighbour-joining method and maximum-parsimony was performed by using bootstrap values based on 1000 replications. The almost-complete $16 \mathrm{~S}$ rRNA gene sequences of the three strains were compared by sequence 
similarity calculations after a neighbour-joining analysis. The results of these calculations indicated that the closest relative of all strains was O. grignonense (99.0 and $98.2 \%$ similarity to the type strain). Lower sequence similarities were found with strains of all other species of the genus Ochrobactrum with validly published names. A phylogenetic tree is shown in Fig. 1.

In recA-based phylogenetic analyses including the type strains of some Ochrobactrum and Brucella species, strain CCUG $38531^{\mathrm{T}}$ clustered as a separate lineage most closely related to Brucella species (Scholz et al., 2006). recA could not be amplified from strains CCUG $30717^{\mathrm{T}}$ and CCUG 43892 , as described previously for the type strain of $O$. grignonense (Scholz et al., 2006).

For quinone and polar lipid analysis, cells were grown on PYE medium (Busse et al., 2005). Detailed results of chemotaxonomic analyses are given in the species description. The following analytical procedures were performed as described: respiratory quinones (Tindall, 1990; Altenburger et al., 1996) but using an HPLC consisting of a JASCO PU 2080 Plus pump and JASCO UV-2075 Plus UV/Vis detector; polyamines (Busse \& Auling, 1988; Busse et al., 1997) using a JASCO PU 2080 Plus pump; polar lipids (Ventosa et al., 1993); and fatty acids (Kämpfer \& Kroppenstedt, 1996). The quinone system (Q-10) supports affiliation of the three strains to the Alphaproteobacteria, where the majority of species (including Ochrobactrum species) have Q-10 as the major quinone (Lechner et al., 1995; Yokota et al., 1992). The polyamine pattern, with the predominant compounds putrescine and spermidine, was in agreement with the patterns reported previously for two species, including O. anthropi (Lechner et al., 1995; Hamana \& Takeuchi, 1998), and is distinct from the polyamine patterns of members of the genera Rhizobium, Mesorhizobium, Sinorhizobium/Ensifer, Aminobacter and Phyllobacterium, which were shown to contain symhomospermidine as the major compound in their polyamine patterns (Busse \& Auling, 1988; Auling et al., 1991; Hamana \& Takeuchi, 1998), whereas spermidine is only present in minor to moderate amounts. In contrast, other relatives, such as species of Pseudaminobacter, exhibit polyamine patterns with the predominant compounds putrescine, spermidine and sym-homospermidine, and Mycoplana bullata shows the presence of spermidine as the major compound with moderate amounts of symhomospermidine (Hamana \& Takeuchi, 1998; Kämpfer et al., 1999). However, in the three strains, we were able to detect significant amounts of sym-homospermidine [9$17 \mu \mathrm{mol}$ (g dry weight) ${ }^{-1}$ ]. Since the Ochrobactrum species examined so far have been reported to lack sym-homospermidine, we have reanalysed all type strains of Ochrobactrum species for their polyamine patterns, and every strain was found to contain at least moderate amounts $\left[>5 \mu \mathrm{mol}(\mathrm{g} \text { dry weight })^{-1}\right]$ of this polyamine (not shown). These results suggest that, under the standardized conditions for growth of biomass applied here (growth on PYE medium at $28{ }^{\circ} \mathrm{C}$ and harvesting the cells at approximately $70 \%$ of the maximum optical density of the culture), Ochrobactrum species are characterized by a polyamine pattern containing the major compound spermidine and moderate to major amounts of putrescine and sym-homospermidine. Absence of symhomospermidine in representatives of the closely related genus Pseudochrobactrum (Kämpfer et al., 2006, 2007; B. Huber and H.-J. Busse, unpublished results) appears to be a distinguishing trait between the two genera. The polar lipid profiles of CCUG $30717^{\mathrm{T}}$ (Fig. 2), CCUG 43892 and CCUG $38531^{\mathrm{T}}$ were almost indistinguishable and exhibited a high degree of similarity to the profile of $O$. gallinifaecis (Kämpfer et al., 2003b). Like this species, the strains showed the presence of aminolipid AL2, but its content in the profile of CCUG $38531^{\mathrm{T}}$ was lower than in the other two strains (not shown). Since AL2 is lacking in extracts of Pseudochrobactrum species (Kämpfer et al., 2006, 2007), its presence is apparently another distinguishing trait between Ochrobactrum and Pseudochrobactrum. In this context, it is worth mentioning here that other Ochrobactrum species also contain this characteristic in their polar lipid profiles (B. Huber and H.-J. Busse, unpublished results).

The fatty acid profiles of the three strains are shown in Table 1. No significant differences in fatty acid profiles have been found for other Ochrobactrum species; however,

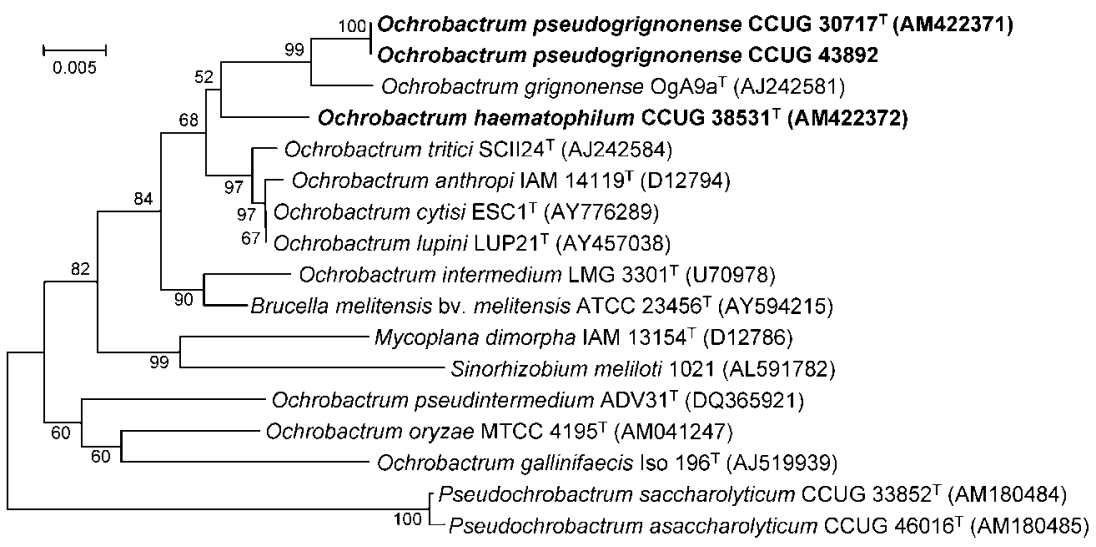

Fig. 1. Phylogenetic analysis based on $16 \mathrm{~S}$ rRNA gene sequences available from the EMBL database (accession numbers in parentheses) constructed after multiple alignment of data by CLUSTAL_x (Thompson et al., 1997). The tree was constructed as described in the text. Bootstrap values based on 1000 replications are listed as percentages at branching points. Bar, 0.005 substitutions per nucleotide position. 


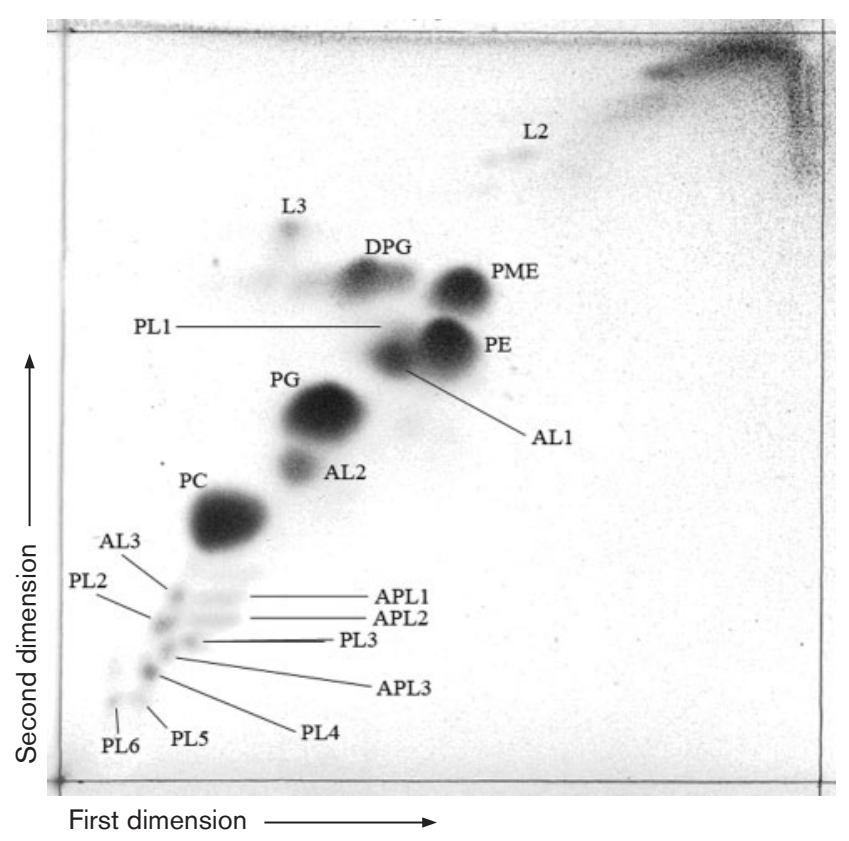

Fig. 2. Two-dimensional TLC of polar lipids of strain CCUG $30717^{\top}$. PME, Phosphatidylmonomethylethanolamine; PE, phosphatidylethanolamine; PC, phosphatidylcholine; DPG, diphosphatidylglycerol; PG, phosphatidylglycerol; $A L 1-3$, unknown aminolipids; PL1-6, unknown phospholipids; APL1-3, unknown aminophospholipids; L2-3, unknown polar lipids.

no hydroxylated fatty acids were detected in strain CCUG $38531^{\mathrm{T}}$.

Results of the physiological characterization are given in the species description and in Table 2 (differential characters), using previously described methods (Kämpfer et al., 1991). DNA-DNA hybridization experiments were performed with all three strains and the type strains of all Ochrobactrum species using the method described by Ziemke et al. (1998), except that, for nick translation, $2 \mu \mathrm{g}$ DNA was labelled during a $3 \mathrm{~h}$ incubation at $15{ }^{\circ} \mathrm{C}$. Results for the novel strains and the four most closely related type strains are shown in Table 3.

Phylogenetic examinations based on almost-entire 16S rRNA gene sequences showed the affiliation of the three strains to the genus Ochrobactrum. They also shared the distinguishing characteristics of the genus, the presence of unknown aminolipid AL2 and a polyamine pattern containing significant amounts of sym-homospermidine in addition to spermidine and putrescine. The relationship of strains CCUG $30717^{\mathrm{T}}$ and CCUG 43892 at the species level as suggested by their identical 16S rRNA gene sequences was confirmed by the results of DNA-DNA hybridizations. In the phylogenetic tree, they were placed next to O. grignonense $\mathrm{OgA9}^{\mathrm{T}}$, but their status as a distinct species was confirmed by DNA-DNA hybridizations with O. grignonense DSM $13338^{\mathrm{T}}$; O. anthropi CIP $14970^{\mathrm{T}}$, O. tritici LMG $18957^{\mathrm{T}}$ and O. intermedium LMG $3301^{\mathrm{T}}$. The
Table 1. Major fatty acids (\%) of the type strains of species of the genus Ochrobactrum closely related to strains CCUG $30717^{\top}$, CCUG 43892 and CCUG $38531^{\top}$

Strains: 1, O. pseudogrignonense sp. nov. CCUG $30717^{\mathrm{T}}$; 2, O. pseudogrignonense sp. nov. CCUG 43892; 3, O. haematophilum sp. nov. CCUG $38531^{\mathrm{T}} ; 4$, O. grignonense DSM $13338^{\mathrm{T}} ; 5$, O. gallinifaecis Iso $196^{\mathrm{T}} ; 6$, O. intermedium LMG $3301^{\mathrm{T}} ; 7$, O. anthropi CIP $14970^{\mathrm{T}} ; 8$, O. tritici LMG $18957^{\mathrm{T}}$. All strains were grown on trypticase soy broth agar at $28{ }^{\circ} \mathrm{C}$ for $48 \mathrm{~h}$ prior to fatty acid analysis. For unsaturated fatty acids, the position of the double bond is located by counting from the methyl $(\omega)$ end of the carbon chain. cis and trans isomers are indicated by the suffixes $c$ and $t$, respectively. -, Not detected.

\begin{tabular}{|c|c|c|c|c|c|c|c|c|}
\hline Fatty acid & 1 & 2 & 3 & 4 & 5 & 6 & 7 & 8 \\
\hline \multicolumn{9}{|l|}{ Saturated fatty acids } \\
\hline $\mathrm{C}_{14: 0}$ & - & - & - & - & 0.7 & - & - & - \\
\hline $\mathrm{C}_{15: 0}$ & - & 0.3 & - & - & - & - & - & - \\
\hline $\mathrm{C}_{16: 0}$ & 9.7 & 9.2 & 10.8 & 2.9 & 8.9 & 3.7 & 6.6 & 3.7 \\
\hline$C_{17: 0}$ & 1.6 & 2.1 & 2.5 & 1.7 & - & 3.1 & 1.4 & 0.9 \\
\hline $\mathrm{C}_{18: 0}$ & 4.9 & 5.0 & 7.7 & 7.2 & 3.7 & 4.1 & 8.8 & 9.6 \\
\hline \multicolumn{9}{|l|}{$\begin{array}{l}\text { Unsaturated fatty } \\
\text { acids }\end{array}$} \\
\hline $\mathrm{C}_{13: 1}$ at $12-13$ & - & - & - & 0.7 & - & - & 0.6 & - \\
\hline $\mathrm{C}_{17: 1} \omega 6 c$ & - & - & - & 0.5 & - & 1.1 & - & - \\
\hline $\mathrm{C}_{18: 1} \omega 7 c$ & 19.2 & 24.2 & 32.7 & 31.6 & 28.8 & 25.8 & 45.6 & 77.9 \\
\hline $\begin{array}{r}\text { 11-Methyl } \\
\mathrm{C}_{18: 1} \omega 7 t\end{array}$ & 1.7 & 1.3 & - & 1.0 & 1.6 & 1.5 & 1.0 & - \\
\hline $\mathrm{C}_{20: 1} \omega 7 c$ & - & 0.2 & - & 0.8 & - & - & - & - \\
\hline $\mathrm{C}_{20: 2} \omega 6,9 c$ & 0.9 & 0.3 & 1.2 & 0.8 & 1.1 & 0.9 & 0.5 & - \\
\hline \multicolumn{9}{|l|}{ Hydroxy fatty acids } \\
\hline $\mathrm{C}_{18: 1} 2-\mathrm{OH}$ & 1.8 & 2.0 & - & 0.5 & 1.5 & 1.8 & 0.6 & 1.4 \\
\hline $\mathrm{C}_{18: 0} 3-\mathrm{OH}$ & 0.5 & 0.6 & - & 0.5 & - & - & - & - \\
\hline Summed feature $3^{*}$ & 1.4 & 1.7 & 1.8 & 1.0 & 3.7 & 0.7 & 1.1 & 0.7 \\
\hline \multicolumn{9}{|l|}{ Cyclopropane acids } \\
\hline $\mathrm{C}_{17: 0}$ cyclo & 1.0 & 1.3 & - & - & 2.9 & - & 0.8 & - \\
\hline $\mathrm{C}_{19: 0}$ cyclo $\omega 8 c$ & 57.0 & 50.8 & 43.2 & 50.2 & 47.2 & 57.4 & 32.7 & 5.9 \\
\hline Unknown $13.957 \dagger$ & 0.3 & 0.2 & - & 0.2 & - & - & - & - \\
\hline Unknown $14.959 \dagger$ & - & 0.3 & - & 0.7 & - & - & 0.3 & - \\
\hline
\end{tabular}

${ }^{*}$ Summed features are groups of two or three fatty acids that cannot be separated by GLC with the MIDI system. Summed feature 3 contained $\mathrm{C}_{16: 1} \omega 7 c$ and/or iso- $\mathrm{C}_{15: 0} 2-\mathrm{OH}$.

$\dagger$ Unknown fatty acids have no name listed in the peak library file of the MIDI system and therefore cannot be identified. Values are equivalent chain lengths.

results from DNA-DNA hybridizations also demonstrated that CCUG $38531^{\mathrm{T}}$ is a representative of another species of the genus Ochrobactrum. On the basis of unique phenotypic traits and genotypic characterization, we therefore describe two novel Ochrobactrum species.

\section{Description of Ochrobactrum pseudogrignonense sp. nov.}

Ochrobactrum pseudogrignonense [pseu.do.gri.gno.nen'se. Gr. adj. pseudes false; N.L. neut. adj. grignonense a bacterial 
Table 2. Physiological characteristics of the type strains of Ochrobactrum species closely related to strains CCUG $30717^{\top}, \mathrm{CCUG}$ 43892 and CCUG $38531^{\top}$

Strains: 1, O. pseudogrignonense sp. nov. CCUG $30717^{\mathrm{T}}$ and CCUG 43892; 2, O. haematophilum sp. nov. CCUG 38531 ${ }^{\mathrm{T}}$; 3 , O. grignonense DSM $13338^{\mathrm{T}}$; 4, O. anthropi CIP $14970^{\mathrm{T}}$; 5, O. gallinifaecis Iso $196^{\mathrm{T}}$; 6, O. intermedium LMG $3301^{\mathrm{T}}$; 7, O. tritici LMG $18957^{\mathrm{T}}$. +, Positive; - , negative; $(+)$, weakly positive. All strains were positive for hydrolysis of L-alanine $p$-nitroanilide (pNA) and weak hydrolysis of bis- $p$-nitrophenyl (pNP) phosphate. All strains were negative for hydrolysis of aesculin ${ }^{a \star}, \mathrm{pNP} \beta$-D-galactopyranoside ${ }^{a}$, $\mathrm{pNP} \beta$-D-glucuronide, $\mathrm{pNP} \alpha$-D-glucopyranoside, pNP $\beta$-D-glucopyranoside, pNP phosphorylcholine and 2-deoxythymidine-5' -pNP phosphate. All strains were also positive for assimilation of Larabinose $^{a}, \mathrm{D}$-galactose ${ }^{a}$, gluconate, D-glucose, D-mannose, D-ribose ${ }^{a}, \mathrm{D}$-xylose, acetate, propionate ${ }^{a}$, fumarate ${ }^{a}$, glutarate, DL-lactate, L-malate ${ }^{a}$, oxoglutarate $^{a}$, pyruvate $^{a}$, L-alanine, L-proline, L-serine ${ }^{a}$ and ornithine ${ }^{a}$. All strains were negative for assimilation of $p$-arbutin, salicin, putrescine, Lphenylalanine, L-tryptophan, 3-hydroxybenzoate, adipate ${ }^{b}$, itaconate, mesaconate, phenylacetate ${ }^{a}, \alpha$-D-melibiose ${ }^{a}$ and azelate.

\begin{tabular}{|c|c|c|c|c|c|c|c|}
\hline Test & 1 & 2 & 3 & 4 & 5 & 6 & 7 \\
\hline \multicolumn{8}{|l|}{ Hydrolysis of: } \\
\hline pNP phenylphosphonate & $(+)$ & - & - & - & - & - & $(+)$ \\
\hline L-Glutamate $\gamma$-3-carboxy-pNA & - & - & - & $(+)$ & - & + & $(+)$ \\
\hline L-Proline $\mathrm{pNA}^{b_{\star}}$ & + & + & + & + & + & $(+)$ & $(+)$ \\
\hline \multicolumn{8}{|l|}{ Assimilation of: } \\
\hline $\begin{array}{l}\text { D-Fructose, } \text { myo-inositol }^{a}, \text { L-rhamnose }^{a}, \text { D-sorbitol }^{a}, \text { cis-aconitate, }_{\text {citrate }}{ }^{a b}, \\
\text { DL-3-hydroxybutyrate }\end{array}$ & + & + & + & + & - & + & + \\
\hline 4-Aminobutyrate, $\beta$-alanine ${ }^{a}$ & + & + & + & + & $(+)$ & + & + \\
\hline D-Maltose $^{a b}, N$-acetyl-D-glucosamine ${ }^{a}$ & - & + & - & + & - & + & + \\
\hline Adonitol $^{a c}$ & + & + & - & + & - & + & + \\
\hline Sucrose $\mathrm{e}^{a b}$, trehalose & $+\dagger$ & + & - & + & - & - & + \\
\hline Maltitol & - & + & - & + & - & - & - \\
\hline trans-Aconitate $^{a}$ & + & + & - & - & - & $(+)$ & - \\
\hline D-Cellobiose $\mathrm{e}^{a c}$ & - & - & - & + & - & + & - \\
\hline$N$-Acetyl-D-galactosamine & + & - & + & $(+)$ & - & + & + \\
\hline Suberate $^{a}$ & - & - & - & - & - & - & + \\
\hline L-Aspartate ${ }^{a}$ & + & + & + & + & + & + & - \\
\hline 4-Hydroxybenzoate & - & + & - & $(+)$ & - & $(+)$ & + \\
\hline L-Histidine ${ }^{a}$ & + & + & + & + & + & + & $(+)$ \\
\hline L-Leucine $\mathrm{e}^{a}$ & + & + & + & + & - & + & $(+)$ \\
\hline
\end{tabular}

${ }^{\star}$ Tests (based on different methods) were also performed in the following studies and gave congruent results: $a$, Holmes et al. (1988) with $O$. anthropi; $b$, Velasco et al. (1998) with O. intermedium; $c$, Lebuhn et al. (2000) with type strains of all four previously described species. $\uparrow$ Strain CCUG $30717^{\mathrm{T}}$ showed only weakly positive results.

species epithet; N.L. neut. adj. pseudogrignonense a false (Ochrobactrum) grignonense].

Cells are non-motile, non-spore-forming rods (approx. $2 \mu \mathrm{m}$ in length). Gram-negative and oxidase-positive, showing an oxidative metabolism. Good growth occurs on R2A agar, TSA, nutrient agar and MacConkey agar at $25-30{ }^{\circ} \mathrm{C}$. Growth is observed on PYE agar supplemented with $5 \%$ $\mathrm{NaCl}(\mathrm{w} / \mathrm{v})$ but different results are observed for the two known strains at $7 \% \mathrm{NaCl}$. Growth is observed on PYE agar at $4{ }^{\circ} \mathrm{C}$ but not at $42{ }^{\circ} \mathrm{C}$. Beige, translucent and shiny colonies with entire edges are formed within $24 \mathrm{~h}$, with a diameter of approximately $2 \mathrm{~mm}$. The quinone system consists of Q-10 (96-99\%) and Q-9 (2-4\%). The polyamine pattern [(g dry weight $\left.)^{-1}\right]$ consists of the major compounds spermidine $(23-35 \mu \mathrm{mol})$ and putrescine $(27-34 \mu \mathrm{mol})$, moderate amounts of sym-homospermidine $(9-10 \mu \mathrm{mol})$ and minor amounts of 1,3-diaminopropane (1-2 $\mu \mathrm{mol})$ and spermine $(1 \mu \mathrm{mol})$. Predominant polar lipids are phosphatidylethanolamine, phosphatidylmonomethylethanolamine,

Table 3. Percentage DNA-DNA reassociation values between the novel strains and related Ochrobactrum type strains

\begin{tabular}{|c|c|c|c|c|c|c|c|}
\hline Strain & 1 & 2 & 3 & 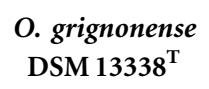 & $\begin{array}{l}\text { O. anthropi } \\
\text { CIP } 14970^{T}\end{array}$ & O. tritici LMG $18957^{\mathrm{T}}$ & $\begin{array}{l}\text { O. intermedium } \\
{\text { LMG } 3301^{\mathrm{T}}}^{\text {L }}\end{array}$ \\
\hline 1. CCUG $30717^{\mathrm{T}}$ & 100 & 81 & 21 & 49 & 26 & 32 & 19 \\
\hline 2. CCUG 43892 & 100 & 100 & 22 & 45 & 48 & 25 & 13 \\
\hline 3. CCUG $38531^{\mathrm{T}}$ & 38 & 13 & 100 & 40 & 18 & 42 & 47 \\
\hline
\end{tabular}


phosphatidylglycerol and phosphatidylcholine. Moderate amounts of phosphatidyldimethylethanolamine, diphosphatidylglycerol and two unidentified phosphorus-free aminolipids (AL1 and AL2) and small amounts of several unknown phospholipids, aminophospholipids and an aminolipid are also present. The fatty acid profile is composed largely of $\mathrm{C}_{18: 1} \omega 7 c(19.2-24.2 \%)$ and $\mathrm{C}_{19: 0}$ cyclo $\omega 8 c(50.8$ $57.8 \%)$. Carbon source utilization and hydrolysis of chromogenic substrates (including differentiating characters for all Ochrobactrum species) are indicated in Table 2.

The type strain, CCUG $30717^{\mathrm{T}}\left(=\mathrm{CIP} 109451^{\mathrm{T}}\right)$, was isolated in 1992 from blood of a 28-year-old man in Göteborg, Sweden. Strain CCUG 43892 was isolated in 2000 from the ear of a newborn in Tromsö, Norway.

\section{Description of Ochrobactrum haematophilum sp. nov.}

Ochrobactrum haematophilum (hae.ma.to.phi'lum. Gr. n. haema -atis blood; Gr. adj. philos loving; N.L. neut. adj. haematophilum blood-loving).

Cells are non-motile, non-spore-forming rods (approx. $2 \mu \mathrm{m}$ in length). Gram-negative and oxidase-positive, showing an oxidative metabolism. Good growth occurs on R2A agar, TSA, PYE agar, nutrient agar and MacConkey agar at $25-30{ }^{\circ} \mathrm{C}$. Growth is observed on PYE agar supplemented with $5 \% \mathrm{NaCl}(\mathrm{w} / \mathrm{v})$ but not with $7 \%$. No growth is observed on PYE agar at 4 or $42{ }^{\circ} \mathrm{C}$. Beige, translucent and shiny colonies with entire edges form within $24 \mathrm{~h}$, with a diameter of approximately $2 \mathrm{~mm}$. The quinone system consists of Q-10 (98\%) and Q-9 (2\%). The polyamine pattern $\left[(\mathrm{g} \text { dry weight })^{-1}\right]$ consists of the major compounds spermidine $(49 \mu \mathrm{mol})$, putrescine $(19 \mu \mathrm{mol})$ and sym-homospermidine $(17 \mu \mathrm{mol})$ and minor amounts of 1,3-diaminopropane $(3 \mu \mathrm{mol})$ and spermine $(2 \mu \mathrm{mol})$. Predominant polar lipids are phosphatidylethanolamine, phosphatidylmonomethylethanolamine, phosphatidylglycerol and phosphatidylcholine. Moderate amounts of phosphatidyldimethylethanolamine, diphosphatidylglycerol and two unidentified phosphorus-free aminolipids (AL1 and AL2) and small amounts of several unknown phospholipids, aminophospholipids and an aminolipid are also present. The fatty acid profile is composed largely of $\mathrm{C}_{18: 1} \omega 7 c(32.7 \%)$ and $\mathrm{C}_{19: 0}$ cyclo $\omega 8 c$ $(43.2 \%)$. Carbon source utilization and hydrolysis of chromogenic substrates (including differentiating characters for all Ochrobactrum species) are indicated in Table 2.

The type strain, CCUG $38531^{\mathrm{T}}\left(=\mathrm{CIP} 109452^{\mathrm{T}}\right)$, was isolated in 1997 from blood of a 79-year-old man in Falun, Sweden.

\section{Acknowledgements}

The CCUG is grateful to the depositors and to the devoted staff Elisabeth Inganäs, Maria Ohlén, Sofia Wernersson and Geneviève Mosella.

\section{References}

Altenburger, P., Kämpfer, P., Makristathis, A., Lubitz, W. \& Busse, H.-J. (1996). Classification of bacteria isolated from a medieval wall painting. J Biotechnol 47, 39-52.

Auling, G., Busse, H.-J., Pilz, F., Webb, L., Kneifel, H. \& Claus, D. (1991). Rapid differentiation by polyamine analysis of Xanthomonas strains from phytopathogenic pseudomonads and other members of the class Proteobacteria interacting with plants. Int J Syst Bacteriol 41, 223-228.

Busse, H.-J. \& Auling, G. (1988). Polyamine pattern as a chemotaxonomic marker within the Proteobacteria. Syst Appl Microbiol 11, 1-8.

Busse, H.-J., Bunka, S., Hensel, A. \& Lubitz, W. (1997). Discrimination of members of the family Pasteurellaceae based on polyamine patterns. Int J Syst Bacteriol 47, 698-708.

Busse, H.-J., Hauser, E. \& Kämpfer, P. (2005). Description of two novel species, Sphingomonas abaci sp. nov. and Sphingomonas panni sp. nov. Int J Syst Evol Microbiol 55, 2565-2569.

Gerhardt, P., Murray, R. G. E., Wood, W. A. \& Krieg, N. R. (editors) (1994). Methods for General and Molecular Bacteriology. Washington, DC: American Society for Microbiology.

Hamana, K. \& Takeuchi, M. (1998). Polyamine profiles as chemotaxonomic markers within alpha, beta, gamma, delta, and epsilon subclasses of class Proteobacteria: distribution of 2-hydroxyputrescine and homospermidine. Microbiol Cult Collect 14, 1-14.

Holmes, B., Popoff, M., Kiredjian, M. \& Kersters, K. (1988). Ochrobactrum anthropi gen. nov., sp. nov. from human clinical specimens and previously known as group Vd. Int J Syst Bacteriol 38, 406-416.

Kämpfer, P. \& Kroppenstedt, R. M. (1996). Numerical analysis of fatty acid patterns of coryneform bacteria and related taxa. Can J Microbiol 42, 989-1005.

Kämpfer, P., Steiof, M. \& Dott, W. (1991). Microbiological characterisation of a fuel-oil contaminated site including numerical identification of heterotrophic water and soil bacteria. Microb Ecol 21, 227-251.

Kämpfer, P., Müller, C., Mau, M., Neef, A., Auling, G., Busse, H.-J., Osborn, A. M. \& Stolz, A. (1999). Description of Pseudaminobacter gen. nov. with two new species, Pseudaminobacter salicylatoxidans sp. nov. and Pseudaminobacter defluvii sp. nov. Int J Syst Bacteriol 49, 887-897.

Kämpfer, P., Dreyer, U., Neef, A., Dott, W. \& Busse, H.-J. (2003a). Chryseobacterium defluvii sp. nov., isolated from wastewater. Int J Syst Evol Microbiol 53, 93-97.

Kämpfer, P., Buczolits, S., Albrecht, A., Busse, H.-J. \& Stackebrandt, E. (2003b). Towards a standardized format for the description of a novel species (of an established genus): Ochrobactrum gallinifaecis sp. nov. Int J Syst Evol Microbiol 53, 893-896.

Kämpfer, P., Rosselló-Mora, R., Scholz, H. C., Welinder-Olsson, C., Falsen, E. \& Busse, H.-J. (2006). Description of Pseudochrobactrum gen. nov., with the two species Pseudochrobactrum asaccharolyticum sp. nov. and Pseudochrobactrum saccharolyticum sp. nov. Int J Syst Evol Microbiol 56, 1823-1829.

Kämpfer, P., Scholz, H., Huber, B., Thummes, K., Busse, H.-J., Maas, E. W. \& Falsen, E. (2007). Description of Pseudochrobactrum kiredjianiae sp. nov. Int J Syst Evol Microbiol 57, 755-760.

Kumar, S., Tamura, K., Jakobsen, I.-B. \& Nei, M. (2001). MEGA2: molecular evolutionary genetics analysis software. Bioinformatics 17, 1244-1245.

Lebuhn, M., Achouak, W., Schloter, M., Berge, O., Meier, H., Barakat, M., Hartmann, A. \& Heulin, T. (2000). Taxonomic characterization of Ochrobactrum sp. isolates from soil samples and wheat roots, and description of Ochrobactrum tritici sp. nov. and Ochrobactrum grignonense sp. nov. Int J Syst Evol Microbiol 50, 2207-2223. 
Lechner, U., Baumbach, R., Becker, D., Kitunen, V., Auling, G. \& Salkinoja-Salonen, M. (1995). Degradation of 4-chloro-2-methylphenol by an activated sludge isolate and its taxonomic description. Biodegradation 6, 83-92.

Ludwig, W., Strunk, O., Westram, R., Richter, L., Meier, H., Yadhukumar, Buchner, A., Lai, T., Steppi, S. \& other authors (2004). ARB: a software environment for sequence data. Nucleic Acids Res 32, 1363-1371.

Scholz, H. C., Tomaso, H., Al Dahouk, S., Witte, A., Schloter, M., Kämpfer, P., Falsen, E. \& Neubauer, H. (2006). Genotyping of Ochrobacterium anthropi by recA-based comparative sequence, PCR-RFLP, and 16S rRNA gene analysis. FEMS Microbiol Lett 257, $7-16$.

Teyssier, C., Marchandin, H., Jean-Pierre, H., Masnou, A., Dusart, G. \& Jumas-Bilak, E. (2007). Ochrobactrum pseudintermedium sp. nov., a novel member of the family Brucellaceae, isolated from man. Int J Syst Evol Microbiol 57, 1007-1013.

Thompson, J. D., Gibson, T. J., Plewniak, F., Jeanmougin, F. \& Higgins, D. G. (1997). The CLUSTAL_X windows interface: flexible strategies for multiple sequence alignment aided by quality analysis tools. Nucleic Acids Res 25, 4876-4882.

Tindall, B. J. (1990). A comparative study of the lipid composition of Halobacterium saccharovorum from various sources. Syst Appl Microbiol 13, 128-130.

Tripathi, A. K., Verma, S. C., Chowdhury, S. P., Lebuhn, M., Gattinger, A. \& Schloter, M. (2006). Ochrobactrum oryzae sp. nov., an endophytic bacterial species isolated from deep-water rice in India. Int J Syst Evol Microbiol 56, 1677-1680.

Trujillo, M. E., Willems, A., Abril, A., Planchuelo, A. M., Rivas, R., Ludeña, D., Mateos, P. F., Martínez-Molina, E. \& Velázquez, E. (2005). Nodulation of Lupinus by strains of the new species Ochrobactrum lupini sp. nov. Appl Environ Microbiol 71, 1318-1327.

Velasco, J., Romero, C., López-Goñi, I., Leiva, J., Díaz, R. \& Moriyón, I. (1998). Evaluation of the relatedness of Brucella spp. and Ochrobactrum anthropi and description of Ochrobactrum intermedium sp. nov., a new species with a closer relationship to Brucella spp. Int $J$ Syst Bacteriol 48, 759-768.

Ventosa, A., Marquez, M. C., Kocur, M. \& Tindall, B. J. (1993). Comparative study of "Micrococcus sp." strains CCM 168 and CCM 1405 and members of the genus Salinicoccus. Int J Syst Bacteriol 43, 245-248.

Yokota, A., Akagawa-Matsushita, M., Hiraishi, A., Katayama, Y., Urakami, T. \& Yamasato, K. (1992). Distribution of quinone systems in microorganisms: Gram-negative Eubacteria. Bull Jpn Fed Cult Coll 8, 136-171.

Ziemke, F., Höfle, M. G., Lalucat, J. \& Rosselló-Mora, R. (1998). Reclassification of Shewanella putrefaciens Owen's genomic group II as Shewanella baltica sp. nov. Int J Syst Bacteriol 48, 179-186.

Zurdo-Piñeiro, J. L., Rivas, R., Trujillo, M. E., Vizcaíno, N., Carrasco, J. A., Chamber, M., Palomares, A., Mateos, P. F., Martínez-Molina, E. \& Velázquez, E. (2007). Ochrobactrum cytisi sp. nov. isolated from nodules of Cytisus scoparius in Spain. Int J Syst Evol Microbiol 57, 784-788. 